\title{
International HR Assignment in Recruiting and Selecting: Challenges, Failures and Best Practices
}

\author{
Lily Thoo \\ Executive MBA Student \\ Open University Malaysia, \\ Jalan Sultan Ismail, 50480 Kuala Lumpur, Malaysia \\ Tel: 60-12-622 5600 E-mail: lily6006@hotmail.com \\ Maniam Kaliannan \\ School of Business, University of Nottingham Malaysia, \\ Jalan Broga, 43500 Semenyih, Malaysia. \\ Tel: 60-3-89248274 E-mail: maniam.kaliannan@nottingham.edu.my
}

Doi:10.5296/ijhrs.v3i4.4610ＵRL: http://dx.doi.org/10.5296/ijhrs.v3i4.4610

\begin{abstract}
This study attempts to examine various issues pertaining to the complexities of international assignment, one of the major dimensions of International Human Resource Management (IHRM). It is our hope that by deep understanding of the uniqueness of international staffing policies, root causes of expatriate failure as well as the challenges encountered by expatriates; a more strategic IHRM approach can then be strategized by multinational corporations (MNCs) taking into consideration of some personalized best practices in effort to avoid or reduce the chances of international assignment failures in future.
\end{abstract}

Keywords: Staffing policies; assignment failures; expatriate challenges; best practices.

\section{Introduction}

Nowadays, globalization frequently takes place for companies around the world. What actually make globalization such an attractive move luring countless multinational companies (MNCs) in setting up branches/ subsidiaries or establishing strategic alliances thousands of miles away from their home country?

The following are some of the forces contributing towards today's globalization: -

1.1 Knowledge transfer (tacit, technical and managerial) Reiche \& Harzing (2008 - 2009)

1.2 Control and coordination. Reiche \& Harzing (2008 - 2009)

1.3 The commercial opportunities provided by the emerging markets. CIPD: http://www.cipd.co.uk

1.4 Build management team with international exposure of operating companies. CIPD: http://www.cipd.co.uk 
1.5 To enter newer markets, i.e. to overcome domestic market saturation. HCR Group (2012), Rothaermel (2013)

1.6 Merger \& acquisitions (M\&As)

\subsection{Company's quest to achieve competitive advantage}

1.8 To gain access to low-cost input factor. Rothaermel (2013)

With rapid development of globalization, activities associated with the traditional human resource management (HRM), including but not limited to human resource planning, staffing, performance management, training and education, compensation and benefits and labour relations undertaken by organizations to utilize its human resources effectively has evolved as international human resource management (IHRM). Dowling \& Welch (1999)

As a result of IHRM evolution, the related HRM activities have encompassed to be more complex and strategic to include further functions such as international taxation, international relocation, administrative services to expatriates, training and appraising home and host countries' employees, inter-government relations, etc. Sameer \& Vrinda (2011). Sequerth (Atlantic International University).

IHRM distinctively differs from the local HRM due to the complexities associated with international assignments of the expatriates such as greater involvement with expatriate's personal lives risk exposure, i.e. threat from terrorism, external influence from the political and economic dimension as well as the complexity from the host country where the attitudes of senior management can greatly differ from one country to the other and extent of their reliance from MNCs. Dowling, Welch, Schuler \& Randall. (1999).

A more strategic IHRM approach is seen as vital in order to complement MNC's globalization goals and in ensuring successful international assignment of its expatriates.

\section{International Staffing Policies}

For key positions such as Managing Director or CEO of MNCs, there are numerous options of international staffing policies available. Ultimately, it is important to carefully consider and select a policy best suited subject to the factors such as MNC's structure, budget, and duration of international assignment, qualification and capability of host country nationals (HCNs), etc. in ensuring success at the end of the day. The manager's nationality is the determining factor of category and it is a major driver influencing the compensation. Dowling, Festing, \& Engle (2008)

Perlmutter (1969) has identified the staffing policy of ethnocentric as a policy chosen when MNC is appointing managers from parent country nationals (PCNs). Key decisions are made at Headquarters (HQ) and few foreign subsidiaries have autonomy. In the ethnocentric view, senior management and technology experts usually would be all PCNs and there is not much room for promotions of HCNs to HQ. Sequerth (Atlantic International University).

According to an empirical study, Harzing (2001a) found that Japanese MNCs are much inclined towards appointment of a PCN as their Managing Director in overseas subsidiaries, as compared to the European MNCs; while MNCs from the financial sector and automobile industry had the highest percentage of PCNs as their Managing Directors.

Bear in mind that with ethnocentric staffing policy, the responsibility of successful recruitment and selection for the best-fit global manager, i.e. an employee with a global 
mindset entrusted with the international assignment falls on to the shoulder of the international HR Manager of the said MNC. These global managers are often internally recruited due to their sound job knowledge as well as great understanding of parent company history, structure, policies and procedures. One of the immediate key issues awaiting the international HR Managers would be to persuade the superior in getting his agreement to release or recommend his best employees for the said international assignment. (http://cws.cengage.co.uk)

For MNCs adopting polycentric staffing policy, they would focus on the appointment from HCNs and it is best adopted with the presence of host country's government imposed foreigner hiring barriers. There is not much room for promotions of HCNs to the corporate office of HQ.

The geocentric staffing policy is adopted by MNCs when they appoint the best qualified candidate for international assignments, regardless of his or her nationality and this could include those from the third country nationals (TCNs). In this case, both employees of PCN and $\mathrm{HCN}$ have equal chance for career advancements and promotions. Sequerth M. (Atlantic International University).

There is another emerging approach called regiocentric staffing policy whereby managers are transferred on regional basis, and this usually forms a mid-way station between a pure polycentric/ ethnocentric approach and it is a truly geocentric approach. Heenan \& Perlmutter (1979)

\subsection{Myths of Global Managers}

It is imperative for us to learn about some of the following common myths of surrounding global managers in order to be able to critically examine the international assignment recruitment and selection criteria at a later stage: -

\subsubsection{Universal approach to global management}

Contrary to common misbelieve, empirical study has shown this to be otherwise. Adopting an ethnocentric attitude of transferring home-based best practices to the Host Country National $(\mathrm{HCN})$ without due consideration of various associated factors may not be workable and may create cultural clash in the host country.

\subsubsection{Multicultural adaptability and behaviours can be acquired}

Individual reacts differently in a foreign environment and the multicultural adaptability may not be acquired to every manager. The success depends on the effectiveness of skill, i.e. manager's ability to successfully translate the required managerial and technical in HCN as well as coping skill, i.e. the ability of the manager to become reasonable comfortable in the $\mathrm{HCN}$.

2.1.3 There are common characteristics shared by successful global mangers

While it is undeniable that some common qualities such as intelligence, motivation, adaptability and entrepreneurship as mentioned by Baruch (2002) and experience are likely to result in the higher success rate of a global manager in $\mathrm{HCN}$, this cannot be solely assumed to be the only contributing factor towards successful international assignment as people react differently in foreign land, under different circumstance.

2.1.4 There are no impediments to mobility

Company may become global in its operations but not its employees as it is influenced by 
barriers such as time and cost constraints, employee availability, host government regulations, etc. Foster (2000)

\section{Failures of International Assignment}

In order to carefully study and effectively execute a successful international recruitment and selection criteria, it is of paramount importance for MNCs and IHRM practitioners to understand some of the documented failures of international assignment.

The usual length of an international assignment spans from 2 to 5 years, according to assignment requirements and project complexity.

Generally, the failure of an international assignment, or sometimes referred to as an "expatriate failure", is defined as the expatriate's premature return to his or her home country prior to the completion of his or her actual assignment duration. (http://cws.cengage.co.uk). However, the definition of expatriate failure should be more pluralistic to include under-performance and repatriation failure. Reiche \& Harzing, (2008 - 2009).

The failure of U. S. international assignments for example, was estimated to be $20 \%-40 \%$ range, i. e. 3 - 4 times higher than the failure rates of other Asian or European expatriates; which perhaps justifies the reason that MNCs from US prefer to send Europeans or Asians for foreign assignments. Runzheimer Report on Relocation, (2002).

\subsection{Cost of Expatriate Failure}

The direct costs associated with international assignment failure such as costs for relocation, airfares, training, cost of living adjustment (COLA) or hardship cost (sometimes applicable); apart from expatriate's salary and allowances, etc. are usually quantifiable.

However, it is the indirect costs such as loss of market share, difficulties with host country government officials, the damaged rapport with HCNs' stakeholders such as local employees and customers, low morale and low productivity from both HCN and the expatriate, severed relationship with overseas customers, etc. which will impact more long-term negative consequences to both the MNCs as well as the expatriate concerned. (http://cws.cengage.co.uk).

\subsection{Reasons of Expatriate Failure}

Due to the fact that both direct and indirect costs associated with expatriate assignment failure are insurmountable to be quantified as above-mentioned, it is important for MNCs to carefully study some of the following documented reasons contributing towards the costly expatriate failure. CIPD: http://www.cipd.co.uk : -

3.2.1 A new business requirement which has greater priority and this could be either in the assignee's home country or in another host country.

3.2.2 Family problems from spouse/ partner, children or even aging parents could significantly cause an expatriate failure. The inability of global manager's family member(s) to make positive cultural adaptation in the host country pertaining to culture, norm, weather, customs, language, education system, etc. can effectively pose as one of the major reasons for such failure which shall not be overlooked. Adding to the complication are some rigid governmental policies towards foreign expatriate employment. One such example indicated by Selmer et al that spouses and children of Chinese expatriates in Hong Kong were normally not permitted to accompany the expatriates! Despite empirical studies over the link between 
favourable adjustment between expatriate's family members and expatriate's adjustment, a survey found that overall; fewer MNCs involve the spouse of partner of the expatriate in the selection process. Price Waterhouse (1997), let alone consider the feelings of expatriate's families on international assignments. Swaak, (1995).

3.2.3 Lack of skills and competency could well translates to an outcome of inappropriate selection practice as mentioned in the provocatively-titled article "The coffee machine system: how international selection really works" as argued by Harris \& Brewster (1999).

3.2.4 Job does not meet expectations results in expatriate's under-performing in international assignment and it failed to meet the goals and targets set by the MNCs.

3.2.5 Inability to adapt to local culture (cultural shock) will result in many expatriates found to be difficult to adjust to a new culture, hence they tried to impose the home office values and cultures to the host country without due considerations instead, often causing cultural clashes as well as misunderstanding in the end. (http://ebooks.narotama.ac.id)

During an interview, a seasoned HR practitioner of a Malaysian conglomerate indicated a peculiar case study about how Malaysian Indian expatriates had failed repeatedly in their India assignments, citing the reason of integration difficulty that resulted in cultural clash. On the contrary, the same conglomerate has not experienced any expatriate failures with other races, i.e. Malaysian Chinese or Malaysian Malay assigned for India assignments. According to feedback from the host country; Malaysian Chinese and Malaysian Malays are more tolerant towards their cultural difference, hence they demonstrate moderation and able to integrate better. In turn, they succeeded in their international assignments. This example indicates the expatriate selection complexity as based on general assumption; Indians would be able to integrate in India far better than any other race due to language and cultural similarities, but it has repeatedly proven to be otherwise in this case. Hence, MNCs need to adopt measures best applied in their industry, and the one-size-fits-all rule certainly cannot be applied in all industries.

3.2.6 Lack of communication from HQ (career blockage) often made expatriates feel that they have been "forgotten" and "sidetracked" by their home office while that their other colleagues are steadily climbing the corporate ladder in home country. It is hence imperative for MNCs to keep transparent and constant communication flow with the expatriate while he or she is on an international assignment to avoid any communication breakdown. A McKinsey Survey has indicated that many managers of MNCs are reluctant to become expatriates due to their fear that relocating will damage their career progress. BusinessWeek. (2008). Technological advancement such as internet, Smartphone, social media network, tele-conferencing, etc. can effectively serve as useful tools for consistent and reliable communication in our borderless world.

3.2.7 Insufficient compensation. Financial aspect plays an important motivation for an expatriate to strive during international assignment. Hence, appropriate benchmarking (looking into expatriate's taxation issue where the expatriate is liable for taxes both in home as well as in host country) would serve as a tool to ensure market competitiveness.

3.2.8 Indication of an international assignment success, i.e. an international assignment could have been accomplished in less time than the originally anticipated time line as argued by Harzing \& Christensen (2004). This is as a matter of fact, good news to MNCs and should be 
seen as success rather than failure.

\section{Challenges of Dual Career Expatriates}

Dual career couples can be broadly defined as both partners earning an income and psychologically committed to their respective career. With the increase in the number of dual career couples in the worldwide trend, this could pose as one of the major dilemmas, both for the MNCs as well as expatriates alike. (http://cws.cengage.co.uk).

In the latest Brookfield Global Relocation Trends Survey, data indicated that $80 \%$ of international assignees are accompanied with their spouses or partners. Reiche (2011). In another study conducted by Tung, it was documented that most MNCs from US ranked "the inability of spouse to adjust" as the main reason of expatriate failure.

Meanwhile, other surveys of US and European MNCs continue to agree with the fact that the leading cause is the spouse and family's inability to adjust to life in a foreign country as expatriate failure. In order to ensure an international assignment success, the expatriate's spouse has to find meaning endeavors abroad, but very often, the challenge of host country's local employment protection hinders the expatriate's spouse from finding careers abroad. Peng (2011).

While much has been talked about the above "the inability of spouse to adjust", but what exactly are the issues of dual career couples when abroad, so much so that it is posing such a threat to the early-exit of an expatriate??? Verma (2010) has enlisted the following issues of dual-career couples which serve as the contributing factors towards expatriate failure: -

\subsection{Culture shock}

This is especially evident for spouse who has not had any previous travelling exposure. She may suffer substantial culture shock while in the host country (especially due to the huge culture difference with her home land) and shut herself away from the world. Under such circumstance, the expatriate may decide to return home prematurely rather than risk his wife's emotional, physical, and psychological health, and possibly their marriage in the end.

\subsection{Obvious differences in the living conditions}

This is usually the case for couples living who used to live in the developed nation and assigned to under-developed or developing host country with a huge gap of living conditions.

\subsection{Language barrier}

Sometimes, spouses who are not bilingual in the host country language may feel alienated due to daily communication difficulty with the local community.

\subsection{Local employment protection \& other local administrative bureaucracy}

As earlier mentioned, the preference to hire local employees from the host country usually result in the inability of expatriate's spouse in finding employment. This will subsequently result in a loss of family income which can be crucial, especially for host countries with high living standards.

When Eric Phillips, a 10-year AT\&T veteran was assigned for international assignment to Brussels, Belgium, his wife, Angelina, had to give up her well-paid career back home as a Market Researcher, which left Angelina difficult to adjust in the host country. Oster, (1993). Newsline (2002).

During a recent interview, Ai Lee, an ex-HR practitioner of a telecommunication service 
provider, had indicated a unique case study during her tenure with the company some years' ago. The management had assigned their US nationality employee with an accompanied Australian partner for an international assignment in China. The assignment was delayed for months due to the hiccup of them securing insurance coverage for his partner. According to the Chinese insurers, as they are not legally married, the partner is hence not recognized as the legal spouse for any insurance coverage in China; albeit the fact that they produced the duly signed Domestic Partnership Registration (an official document certifying their legal relationship permitted under the laws of the State and City of New York for couples that have a close and committed personal relationship). So, it must be reminded that what is legally recognized in one country may not be so in another.

\subsection{Lack of recognition}

As spouse fails to work in the host country, she may feel unrecognized as compared to her home country, especially for the case where the spouse had previous successful career track record in her home country. The loss of an important role in one's life can cause negative effects and reduced one's self-esteem.

\subsection{Lack of support}

Spouse often indicates the lack of support, either from the expatriate's HQ and the host country. They literally had to rely on information from the travel magazine, online travel portal, etc. regarding host country updates. The lack of inaccurate or irrelevant information provided to the spouse of expatriate may result in her perception regarding the issue of lack of support.

\subsection{Isolation}

Spouse often feels isolated due to the limited interaction and network contacts in the new place, far away from relatives and friends and the psychological suffering can be detrimental. 3.8 Lack of recognition of foreign qualifications \& employment opportunity

As expatriates are usually assigned from HQ of a developed nation to the host country of emerging economies, the issues of lack of foreign qualification recognition and employment opportunity were often cited.

\subsection{Visa restrictions}

This issue has long been established as a hindrance as without local employment record or local sponsors, the spouse normally cannot secure a visa at the foreign land.

\section{International Assignment Selection}

It is with the hope that by greater understanding towards various underpinning issues of international assignment failures, MNCs would be able to learn from the lessons of their predecessors and be able to implement effective measures towards ensuring the success of candidate selection. Tung (1981) has identified the following 4 main criteria of a successful international assignment selection process: -

\subsection{Technical competency}

Technical competency was viewed as the most critical criterion due to the fact that the expatriate will be located at some distance from the HQ where technical consultation would not be immediately available, should the need arises. Hence, the expatriate is expected to possess sound technical know-how and be able to independently handle technical issues 
during his overseas assignment.

\subsection{Personal traits}

As the ability to understand diverse culture, effectively interact with people of diverse nationality and ethnic background would ensure smooth transition of an expatriate's international assignment, the expatriate's ability to live and work under a value system, beliefs, manners and way of conducting business which may greatly differ from the expatriate's own would not be seen as an issue under such circumstance.

In other words, the expatriate is required to possess a certain degree of cultural toughness such as the ability to withstand cultural shock, past work experiences with diverse cultures, previous overseas travel history, knowledge of host country language, etc. (MBA Knowledge Base) and be able to withstand the initial cultural shock and be expected to be able to solve problems within different frameworks in the host country.

\subsection{Ability to cope with environment variables}

In addition to understanding the domestic context of PESTLE (Political Economic Social Technological Legal Environment), an expatriate is expected to possess sound understanding on the macro environment from the host country, especially the political, legal or socioeconomic aspects in order to effectively integrate the MNC's daily and strategic direction with the host country. The ability of expatriate's sound PESTLE understanding not only facilitates international assignment, it will also serve as an added strength for effective strategy formulation in the host country.

\subsection{Family situation}

The ability of the expatriate's family, especially the spouse or partner to positively adjust in a foreign environment has often become an increasingly important issue. Adding to the complexity would be the issue of dual-career couples, i.e. the expatriate's partner has to give up his or her career in support of the other's international assignment.

Other selection criteria for international assignment are also commonly considered by MNCs (MBA Knowledge Base): -

\subsection{Leadership ability}

International expatriate assignment often involves expatriate holding key management position who becomes a role model in the host country by default due to position seniority, the candidate's ability to display mature and positive leadership as well as his or her ability to influence the subordinates is often considered as one of the crucial criterion.

\subsection{Physical \& emotional health}

MNCs often struggle to strive for the right balance between an expatriate's health and experience, as studies showed that younger managers (who are usually healthier by nature) are more eager for international assignments. But on the other hand, their lack of management expertise and the required sound technical skills often question MNCs whether these young managers are the right candidates for such an important international assignment. 4.7 Motivation for international assignment

It is of the opinion that global managers must be genuinely motivated to believe in the importance of such overseas assignment. Additionally, global managers must genuinely believe that such international assignment opportunity would increase his or her chance for 
promotion, improve financial status, etc.

\section{Expatriate Selection in Practice}

Though various empirical studies have documented technical competency and personality characteristic to be to on the top of MNCs' selection criteria, most MNCs only used technical competence and knowledge of company system as their selection criteria ironically. Harris \& Brewster (1999a), Morley \& Flynn (2003), Sparrow, Brewster \& Harris (2004).

In the latest data collected via a research, it was found that a stunning $78 \%$ of expatriates indicated that they had not undertaken any selection test, $12 \%$ of the expatriates responded that they were tested on cultural knowledge of host country, while only 5\% expatriates had undergone aptitude test. Sameer \& Vrinda (2011).

The provocative article entitled "The coffee-machine system: how international selection really works" has further outlined how the global manger's selection was often done based on spur of the moment, closed/ informal systems without taking into consideration regarding the true qualities needed. In this scenario, one of such would be the process starting with a senior line manager who is joined by a colleague while waiting for his coffee at the coffee-machine! The decision in fact, has already been taken neither with consideration of the restricted pool of candidates nor the need for candidates to be formally evaluated to ascertain suitability. Harris \& Brewster (1999).

The MNC is clearly adopting a reactive approach rather than strategic approach in the above scenario. As a result, the IHRM would usually involve in the financial aspects and providing practical arrangements of such assignment. Harris \& Brewster (1999a)

\section{International Assignment Selection Best Practices}

Due to the fact that expatriates are normally assigned for international assignments at a distant location, any selection mistakes are likely to be left noticed, until it is too late! (http://ebooks.narotama.ac.id). However, concerted efforts should be made by MNCs towards minimizing the chances of expatriate failure by adhering to the following IHRM best practices: -

\subsection{Emphasize on cultural sensitivity}

Interview with the expatriate must be conducted with great emphasis on his or her ability to relate with people of diverse background. Additional in-depth interviews with the expatriate's manager, co-workers and subordinates will further establish the expatriate's suitability for such assignment.

\subsection{Selection board of expatriate}

Many IHRM practitioners strongly recommend establishing a selection board of expatriate consisting of managers or superiors who have worked with the expatriate for a period of $3-5$ years. These managers or superiors are more able to detect any potential problems due to their familiarity with the expatriate concerned. Minter (2008) Csizmar (2008) Liu \& Lee (2009).

\subsection{Past international experience}

Expatriates who have already spent some time abroad in different countries are more lightly 
to succeed in their international assignments than those who had not been abroad. In view of this, universities such as UCLA and University of Southern California have established global collaboration with overseas universities and businesses to expose their students abroad in equipping them with the necessary diverse cultural, language and customs exposure prior to undertaking the actual overseas assignments upon their joining of the corporate world at a later stage.

\subsection{Screening of expatriate's spouse and family members}

The unhappiness of expatriate's spouse/ partner or family members can potentially cause an international assignment failure, it is always wise to conduct in-depth interviews with the spouse/ partner and family members to determine whether they can withstand the pressure while abroad. Ford and Exxon are two such MNCs that conduct spouse and family members' assessment for qualities such as flexibility, patience and adaptability. Tung (2008), Shellenbarger (1991).

\subsection{Explore the possibility of "foreign born" employees to be MNCs'future expatriate}

Japanese MNCs are found it to be beneficial to hire young foreign nationals (non-Japanese) straight out from college and work in home office in Japan prior to assigning them for international assignment. The strategy works well as these young foreigners have a fresh mind and it is easier to instill the Japanese values and philosophy on them. Some MNCs from US such as Coca-cola have been adopting a similar practice for years and found it to be successful. Steers, Sanchez-Runder \& Nardon (2010) Bird \& Makuda (1989).

\section{Expatriate Adjustment Process}

Mendenhall \& Oddou (1985) have provided the following 4 dimensions of expatriate adjustment process in their study. This could be used as a tool to assist the selection process to focus explicitly on candidate's strengths and weaknesses: -

\subsection{Self-orientation dimension}

Activities related to strengthening expatriate's self-confidence, self-esteem and mental hygiene.

\subsection{Other's orientation dimension}

The activities related to enhancement of the expatriate's ability to interact effectively with HCNs.

\subsection{Perceptual dimension}

The expatriate's ability to understand cross-cultural behavior the way they do as well as the ability to reason out the causes of HCNs' behavior.

\subsection{Cultural toughness dimension}

In culturally tough host countries, i.e. country that are culturally very different from the home country, the first 3 dimensions become even more important than culturally similar countries. An average expatriate, though not all, would normally experience various adjustment phases during his international assignment (the duration of each phase differs from one to another) and this process is commonly referred to as the U-Curve in Figure 1 below.

Phase 1 is sometimes termed the honeymoon period as this is the "honeymoon phase" or "tourist phase" of the expatriate with the presence of mixed emotions such as excitement, anxiety and fear of the known upon expatriate's arrival to the host country. 
Gradually, reality sets in overtime with the revelation of real-life experience in the foreign country, coupled with the setting in of homesickness. This is called Phase 2 and this phase can be extremely crucial as the expatriate has to deal with culture shock and various psychological adjustments which may potentially cause assignment failure at this junction.

With the passing of the critical period, enters Phase 3 where the expatriate makes the necessary adjustments to the new environment, new systems, culture, way of conducting business, etc. and the finally, the expatriate progresses to final stage of healthy recovery period called Phase 4.

Figure 1: Adjustment

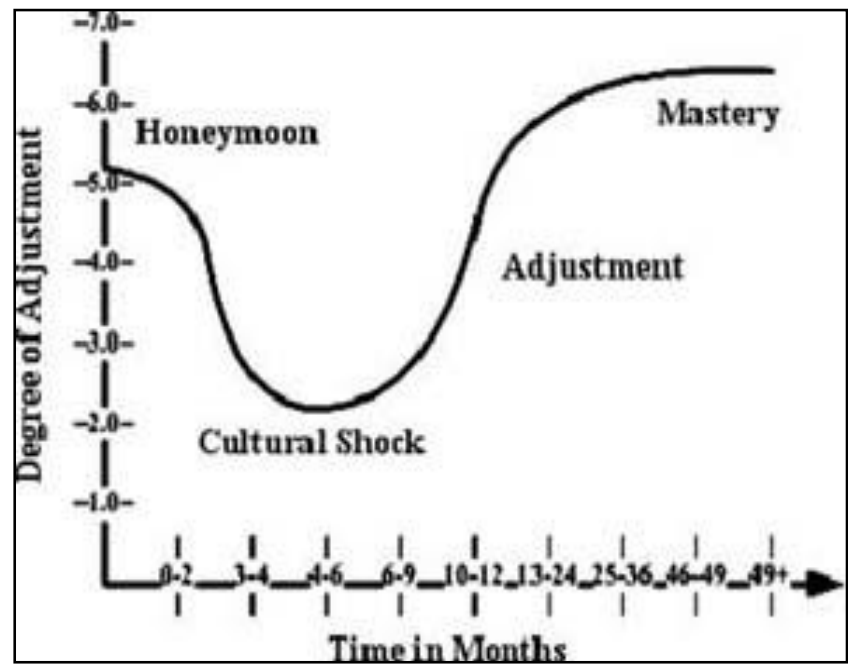

International Assignment (Lund, Daniel W.; Degen, Ronald Jean, Nov/ Dec 2010. Global Business \& Organizational Excellence. Vol. 30 Issue 1, p60-72. 13p. 1 Diagram, 4 Charts, 1 Graph. DOI: 10.1002/joe.20359).

\section{Recommendations}

Once we had a good grasp of various issues and dilemmas of international assignment failures, the following initiatives can be considered for implementation towards a successful international assignment: -

\subsection{Strategic IHRM support}

IHRM practitioners of MNCs need to well-trained in adopting a broader mindset to support the globalization initiatives. It is important for IHRM practitioners to fully understand the dilemmas faced by the expatriate and the spouse/ partner and family and provide strategic IHRM support instead of playing a reactive role.

Contrary to the popular misbelieve, some of the inexpensive yet fundamental initiatives such as the providing appropriate relocating support emergency contact list, assist in job hunting process in host country for the spouse or partner, providing assistance to the spouse' work permit application, organizing events and activities to increase their social integration, identifying appropriate HCN network resources prior to their departure, etc. were considered to be invaluable support in helping their necessary adjustments.

\subsection{Strategic selection approach}

A more strategic selection approach needs to be adopted by IHRM practitioners where potential expatriates must be subjected to former interview process along with necessary test 
for technical and managerial competency. In addition, attention also needs to focus on subjecting the family members of expatriate to undergo an in-depth interview along with "adaptability screening" to ascertain how well the family is likely to withstand the rigors and stress of overseas life. (MBA Knowledge Base). This is viewed as a more holistic approach than the commonly adopted "coffee-machine system" based on emotions as earlier-mentioned.

\subsection{Inpatriation}

Contrary to the tradition expatriation, the innovative option of inpatriation can be considered instead. Inpatriation is a process of transferring employees from $\mathrm{HCN}$ to acquire the skills and knowledge in the home country of the MNC on a temporary or permanent basis. (Harvey, Reiche \& Moeller M. (2011). This option has proven to be more cost-effective.

\subsection{Short-term assignment}

As an alternative to satisfying the need of international assignment, MNCs may consider the option of short-term assignment of $1-12$ months. Collings, Scullion \& Morley (2007). This arrangement will significantly result in less impact for the spouse/ partner as well as the family of expatriate as they need not relocate along under such assignment duration.

\subsection{Commuter assignment}

Under such arrangement, the expatriate commutes from his or her home country to the host country on weekly or bi-weekly basis for work assignments. Reiche \& Harzing, (2008 2009). In this manner, the spouse/ partner need not accompany the expatriate and they can then each focus on their own career without jeopardizing the relationship.

\subsection{Business trips}

Business trip, or sometimes referred to as international business travel, can be organized for assignments to be done via regular business trips of few days or up to few week without creating much impact to the expatriate's family. Welch, Worm \& Fenwick (2003).

\subsection{Virtual assignment}

With the advancement of information technology, virtual assignment has become an increasingly popular mode as an alternative to international assignment as it involves less cost and less complexity. (http://cws.cengage.co.uk)

\subsection{Dual assignment}

For the unavoidable international assignments, perhaps MNCs may also look into the possibility of providing career opportunity to the spouse or partner of expatriate within the same company. This will forge a degree of closeness between the dual-career couples while eliminating family problem in the foreign land, to a certain extent.

\subsection{Employ spouse as mentor to the new expatriate's spouse/ partner}

As cultural shock usually occurs in a foreign land with new environment, different weather, new culture and system, it is practical to appoint the spouse who has positively settled in $\mathrm{HCN}$ as this will provide a form of emotional support, apart from imparting the detailed information of host country in helping the newly arrived spouse to make positive adjustment. In this way, spouse employment opportunity was created in a meaningful way as a new network alliance will be forged in the foreign land.

\subsection{Training and development opportunity}

The support of appropriate training and development programmes should be extended to 
spouse/ partner of the expatriate equipping or updating her with the needed skills and knowledge in order for her to secure gainful employment in the host country.

As English is undoubtedly an important global international language, the issue is not to be overlooked by IHRM is to map out effective and reliable English language training programme to the expatriate's spouse/ partner who is not English-conversant. One can easily imagine the frustrations to be endured for not being able to transact the simplest tasks such as grocery purchasing or banking as a result of communication problem in the foreign soil!

\section{Conclusion}

Insofar, we have gathered certain level of firm understanding on various dimensions and complexities involving the recruitment and selection of staff for international assignments. Issues ranging from international staffing policies, the myths and roles of global managers, reasons of international assignment, expatriate failures as well as the associated costs and reasons, theoretical candidate selection as well as actual selection practice, the issues of dual career couples, key elements of assignment process, international assignment best practices, expatriate adjustment process, right up to some recommendations have been systematically outlined as above.

It is with the hope that this serves as a toolkit as well as a wake-up-call for MNCs and IHRM practitioners that they should seriously look into the appropriate tailor-made measures (not just the one-size-fit all measures) in minimizing international assignment failures which usually involves insurmountable direct and indirect costs beyond justification.

With the change of perception from the younger generation where loyalty can hardly be found in their beliefs, global companies will have a lot more to lose, if the fundamental issues of international assignment are not well managed.

Finally, it is important to link international assignments more directly to the career path of the expatriate concerned in order to capitalize on the skills and experiences gained during his or her transfer. As soon as the expatriate can "see the big picture" regarding a bright future with the right career path within the organization, all the investments and hard work from various parties can then be justified with talent retention upon his or her repatriation to the home country and that the international exposure, experience and skills acquired can then be maximized to the fullest in helping MNCs achieving greater heights...

\section{References}

Bartlett, C. A. and Ghoshal, S. (1997). 'The Myth of the Generic Manager: New Personal Competencies for New Management Roles', California Management Review, Vol. 40. No. 1., 92-116.

Baruch, Y. (2002). 'No Such Thing as a Global Manager', Business Horizons, January-February, 36-4

Bird, A. and Makuda, M. (1989). Expatriates in their own home: A new twist in the human resource management strategies of Japanese MNCs. Human Resource Management, 28(4), 437-453. 
Black, J. S. \& Stephens, G. K. (1989). 'The Influence of the Spouse on American Expatriate Adjustment and Intent to Stay in Pacific Rim Overseas Assignments', Journal of Management, Vol. 15, No. 4., 529-44.

Black, J. S. and Mendenhall, M. (1991). ' The U-Curve Adjustment Hypothesis Revisited \& Theoretical Framework', Journal of International Business Studies, Vol. 22., 225-47.

Brookfield (2011) Global Relocation Trends Survey.

BusinessWeek. (2008). News you need to know, June 16.

Caligiuri, P. (2000). 'The Big Five Personality Characteristics as Predictors of Expatriate's Desire to Terminate the Assignment and Supervisor-rated Performance', Personnel Psychology, Vol. 53, 67-88.

Cengage. [Online]. Available: http://cws.cengage.co.uk/dowling5/students/sample\%20chapters/31017_05_Ch05_p109-136. pdf> (08 Jan 2013)

Collings, D. G., Scullion, H. and Morley, M. J. (2007). 'Changing patterns of global staffing in the multinational enterprise: Challenges to the conventional expatriate assignment and emerging alternatives. Journal of World Business, 42(2): 198-213.

Csizmar, C. (2008). 'Does your expatriate program follow the rules of the road? Compensation and Benefits Review, 40(1), 61-6.

Daniel, W. L. and Degen, R. J. (2010). Global Business and Organizational Excellence. Vol. 30., Issue $1 . \quad$ [Online] Available: $<$ http://ehis.ebscohost.com.newdc.oum.edu.my/eds/results?sid=a6151fa4-0aff-4f83-b7ab-d47 $8 \mathrm{fa} 3 \mathrm{e} 76 \mathrm{ae} \% 40$ sessionmgr14\&vid=3\&hid=3\&bquery=international+journal $+\% 22 \mathrm{of} \% 22+\mathrm{hu}$ man+resource+management $\% 2 c+$ vol. $+2 \% 2 c+$ no.+3\&bdata=JmNsaTA9R1QxJmNsdjA9WSZ 0eXB1PTAmc210ZT11ZHMtbG12ZQ\%3d\%3d> (13 Jan 2013)

Dowling, P. J., Welch, D. E. (1999). International Human Resource Management, $4^{\text {th }}$ Ed, South-Western Publishing.

Dowling, P. J., Welch, D. E., Schuler and Randall, S. (1999). International Human Resource Management: Managing People in a Multinational Context, South Western College Publication.

Dowling, P. J., Festing, M. and Engle, A. D. (2008). International Human Resource Management, $5^{\text {th }}$ Ed, South-Western Publishing.

Harris, H. and Brewster, C. (1999). 'The Coffee-Machine System: How International Selection Really Works', International Journal of Human Resource Management, Vol. 10, No. 3., 488-500.

Harvey, M., Reiche B. S., R. and Moeller M. (2011). 'Developing Effective Global Relationships Through Staffing with Inpatriate Managers: The Role of Interpersonal Trust', Journal of International Management.

HCR Group (2012). [Online] Available: $<$ https://www.hcr.co.uk/?page=BlogandNews\&article=332> (20 Jan 2013)

Heenan, D. A. and Perlmutter, H. V. (1979). Multinational organization development. Reading, MA: Addison-Wesley. 
Harzing, A. W. K. (2001a). Who's in charge? An empirical study of executive staffing practices in foreign subsidiaries. Human Resource Management, 40(2): 139-158.

Harzing, A. W. K. and Christensen, C. (2004). Expatriate failure: Time to abandon the concept? Career Development International, 9(6-7): 616-626.

Liu, C. H. and Lee, H. W. (2009). 'A proposal model of expatriates in multinational corporations, www.emeraldinsight.com

MBA Knowledge Base. [Online] Available:

$<$ http://www.mbaknol.com/international-business/selection-criteria-for-international-assignm ents/> (20 Jan 2013)

Mendenhall, M. and Oddou, G. (1985). 'The Dimensions of Expatriate Acculturation: A review. Academy of Management Review, 10(1): 39-47.

Mendenhall, M. E. and Oddou G., (1988). 'The Overseas Assignment: A Practical Look', Business Horizons (September-October), 78-84.

Minter, R. L. (2008). Preparation of expatriates for global assignment: Revisited. Journal of Diversity Management, 3(20), 37-42.

Morley, M. and Flynn, M. (2003). Personal characteristics and competencies as correlates of intercultural transitional adjustment among U. S. and Canadian sojourners in Ireland. International Management, 7(2): 31-46.

Naumann, E. (1993). "Organizational Predictors of Expatriate Job Satisfaction", Journal of International Business Studies, Vol. 24, No. 1. pp. 61-79. [Online] Available: $<$ http://ebooks.narotama.ac.id/files/Managing\%20Human\%20Resources\%20(7th\%20Edition) /Chapter\%2017\%20International\%20HRM\%20Challenge.pdf> (15 Jan 2013)

Newsline (2002), 'Expatriate activities expands but at a slower rate than expected. www.windhamworld.com

News update by the US Congress Education and the Workforce Committee. [Online] Available: <www.house.gov/ed_workforce/press109/first/04apr/t6042205.htm> (4 May 2006)

Forster, N. (2000). "The Myth of the "International Manager", International Journal of Human Resource Management, Vol. 11, No. 1., 126-42.

Organizational Resource Counselors Inc, 'Dual Careers and International Assignments Survey' (2002). The organization changed its name to ORC Worldwide in 2003.

Oster, P. (1993). 'The fast track leads overseas.' Business Week, 64-68.

Peng, M. W. (2011). 'Global Business', $2^{\text {nd }}$ Ed. South-Western Cengage Learning.

Perlmuter, H. V. (1969). The tortuous evolution of the multinational corporation. Columbia Journal of World Business, 4(1), 9-18.

Price Waterhouse (1997), International Assignments: European Policy and Practice.

Report International Education and Foreign Language Studies in Higher Education (ISBN 0160749123) Published by this Congress Committee in 2005.

Runzheimer Report on Relocation. (2002). U. S. companies impact high level employees. (www.runzheimer.com)

Reiche B. S. and Harzing, A. W. K. (2008 - 2009). International Assignments, International Human Resource Management, London: Sage Publication. [Online] Available: <http://www.harzing.com/download/ihrmchapter.pdf> (09 Jan 2013) 
Reiche B. S. (2011). Expatriatus: If you want to solve expatriates' adjustment problems, don't forget the spouse!, IESE Business School. [Online] Available: $<$ http://blog.iese.edu/expatriatus/2011/09/06/if-you-want-to-solve-expatriates\%E2\%80\%99-a djustment-problems-don\%E2\%80\%99t-forget-the-spouse/> (12 Jan 2013 )

Rothaermel, F. T. (2013) Strategic Management, Concept. The McGraw-Hill Companies, Inc.

Sameer, P. S. and Vrinda, S. (2011). 'An Empirical Study of Expatriate: Expectations in IT/ ITES Sector from Human Resource Management Perspective'. Contemporary Management Research, Vol. 5, No. 2, 68-69.

Selmer, J., Ebrahimi, B.P. and Mingtao, L. (2002). 'Career Management of Business Expatriates from China', International Business Review, Vol. 11, No. 1., 17-33

Sequerth, M. "Global Human Resource Management'. [Online] Available: $<$ http://www.aiu.edu/publications/student/english/Global\%20Human\%20Resource\%20Mana gement.html> (11 Jan 2013)

Shellenbarger, S. (1991). 'Spouses must pass test before global transfers. Wall Street Journal, B-1.

Sparrow, P., Brewster, C. and Harris, H. (2004). Globalizing human resource management. London: Routledge.

Steers, R. M., Sanchez-Runder, C. and Nardon, L. (2010). Management across Cultures: Challenges and Strategies. London: Cambridge University Press.

Swaak, R. (1995). 'Expatriate failures: Too many, too much cost, too little planning.' Compensation and Benefits Reviews, (Nov - Dec) 47-75.

The Chartered Institute of Personnel and Development, UK. 'Managing International Assignment In a Changing World: An overview of key trends and challenges in managing assignments.

[Online]

Available: <http://www.cipd.co.uk/NR/rdonlyres/85E7FFC5-D8DB-4214-8A6D-49911FE184F6/0/Inter nationalAssignments24102012.pdf> (09 Jan 2013)

Tung, R. L. (1982). 'Selection and Training Procedures of US, European and Japanese Multinationals', California Management Review, Vol. 25, No. 1., 57-71

Tung, R. L. (1984). 'Human Resource Planning in Japanese Multinationals: A Model for US Firms?', Journal of International Business Studies, 139-49.

Tung, R. L. (2008). 'Do race and gender matter in international assignments to/ from Asia Pacific? An exploratory study of attitudes among Chinese and Korean executives. Human Resource Management, 47(1), 91-110.

Verma, K. (2010). 'Expatriate Spousal Problems and Feasible Solutions'. [Online] Available: <http://www.indianmba.com/Faculty_Column/FC1158/fc1158.html> (13 Jan 2013)

Welch, D. E., Worm, V. and Fenwick, M. (2003). Are virtual assignments feasible? Management of International Review, 43 (Special Issue 1), 95-114. 